\title{
Potential of sustainable and biological aspect of sting ray (Dasyatis sp.) as catch fisheries status overview in Java Sea
}

\author{
Arif Mahdiana ${ }^{1}$, Norman Arie Prayogo ${ }^{1.2}$. Isdy Sulistyo ${ }^{1}$ \\ ${ }^{1}$ Faculty of Fisheries and Marine Science, University of Jenderal Soedirman, Purwokerto, Indonesia \\ ${ }^{2}$ Center of Maritime and Bioscience, University of Jenderal Soedirman, Purwokerto, Indonesia
}

\begin{abstract}
Stingray fish is a demersal fish commodity in Indonesian waters which decreasing in catch. The purpose of this research is to know the potential of sustainable and some aspects of Stingray fish biology by using the Maximum Sustainable Yield (MSY) indicator as the fishing status in Java Sea. Data of catch and effort taken from production data of year 2006-2015 and primary data to know some aspect of biology is taken at TPI port of Cirebon and Tegal Specification data of fish catching tools Pari obtained from fisherman interview. The data of the catch in the analysis using Surplus Production Method (Schaefer) and observed aspects of stingray biology include: sex ratio and distribution of length of Stingray fish. The results showed the MSY value of Stingray fish was 894.275 tons / year and fMSY value of 34.716 ships / year. The sex ratio of male Stingray fish with female Stingray fish is still balanced, which is 1: 1.34 and the size of long frequency entered into the category of immature fish gonad and fish which first ripe gonad, which ranges between length $16-22 \mathrm{~cm}$ both male fish or female. Based on the research results can be concluded that Stingray fish catchment in Java sea still in sustainable condition.
\end{abstract}

\section{Introduction}

Indonesia's potential of resource is fast, expecially its potential in fisheries. The total diversity of fish strengtened by 5,8 million $\mathrm{km}^{2}$ of seawater and $81.000 \mathrm{~km}$ coastal length [1,2].

Stingray fish is Indonesian catch fisheries commodity, stingray is demersal fish that included in Chondrichthyes class [3]. Java Sea demersal fish potential is 431.000 tons/year with and exploitation value of $56 \%$. Stingray catchment in 2006 was $7,249.70$ tons, it was $16.13 \%$ of total catch fisheries [4]. With stingray demand increased, stingray became main catch of fishermans and have high economical value. It's meat and fin become foods and it's skin become fashion items [5]. Because of high demand, overfishing is occuring and stingray fish stock is declining.

Potential of sustainable is a concept of fish resources management with responsibility to sustain the resources [6]. Based on Marine and Fisheries Research, Departement of Marine and Fishiries Indonesian Institution of Science 2001 [7]. Indonesian seawater fish resources MSY was 6.4 million tons / year with acceptable catch 5.1 million tons/ year ( $80 \%$ of MSY). Demersal fish potential of resource 1,370,090 tons/ year. Reported by Indonesin Directorate of Catch Fisheries on 2011, there was excessive catchment on 2006, causing decline in fish catchment from $925.557 \mathrm{~kg}$ to $841.545 \mathrm{~kg}$ in 2010.

The aim of this study is to give information about stingray fisheries resources management in Java Sea. The observed factors were aspect of fish, sex ratio, and fish legth structure.

\section{Material and Methods}

Methods used in this research are observation survey and interciew to collect primary and secondary data. The primary data is interview done to fishermen using gill net and used as supporting parameter. The secondary data is fishing effort namely total ships and stingray fish production data for 10 years from $2006-2015$. Sample was taken using random 
sampling techinque to fishermen population that catch stingray in Java Sea. The research was done in Tegalsari Fish Auction Place, Tegal, Central Java and Kejawanan Nusantara Fisheries Port Cirebon, West Java. 
Data analyzed using Schaefer production surplus model (1957) stated by Gulland (1983):

$$
q=\frac{\mathrm{h}}{\mathrm{f}}
$$

$$
\begin{aligned}
& \mathrm{q}=\text { CPUE Catch Per Unit of Effort (tons/ship) } \\
& \mathrm{h}=\text { Catch (tons) } \\
& \mathrm{f}=\text { Effort (ship) } \\
& \text { Schaefer MSY and fMSY formula: }
\end{aligned}
$$
a) $f \mathrm{MSY}=-\frac{\mathrm{a}}{2 b}$
b) $M S Y=\frac{\mathrm{a}^{2}}{4 \mathrm{~b}}$
$\mathrm{a}=$ intercept
$\mathrm{b}=$ slope

Type, sex ratio, and size of stingray fish were analyzed descriptively with table and figure.

\section{Result and Discussion}

\subsection{Catch Per Units of Effort (CPUE)}

CPUE of stingray fish from $2006-2015$ :

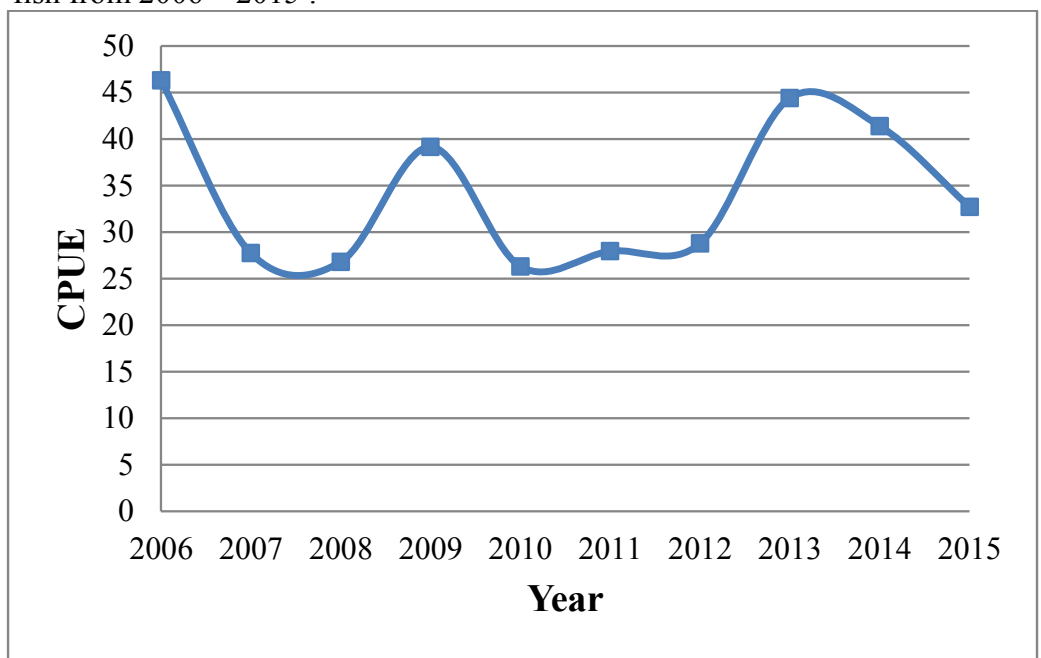

Fig. 1. Stingray Fish CPUE Graphic

The change in CPUE value (figure 2) each year was affected by changes in total ship (effort). CPUE value is inversely proportional to effort value, increase in effort would decrease CPUE value. Resources will depleted faster if effort to expoit increasing. CPUE is affected by increased effort occured to increase production. The decrease in effort will increasing CPUE.

\subsection{Relation between Catch Effort and CPUE}

Relation between catch and effort of stingray fish from $2006-2015$ : 


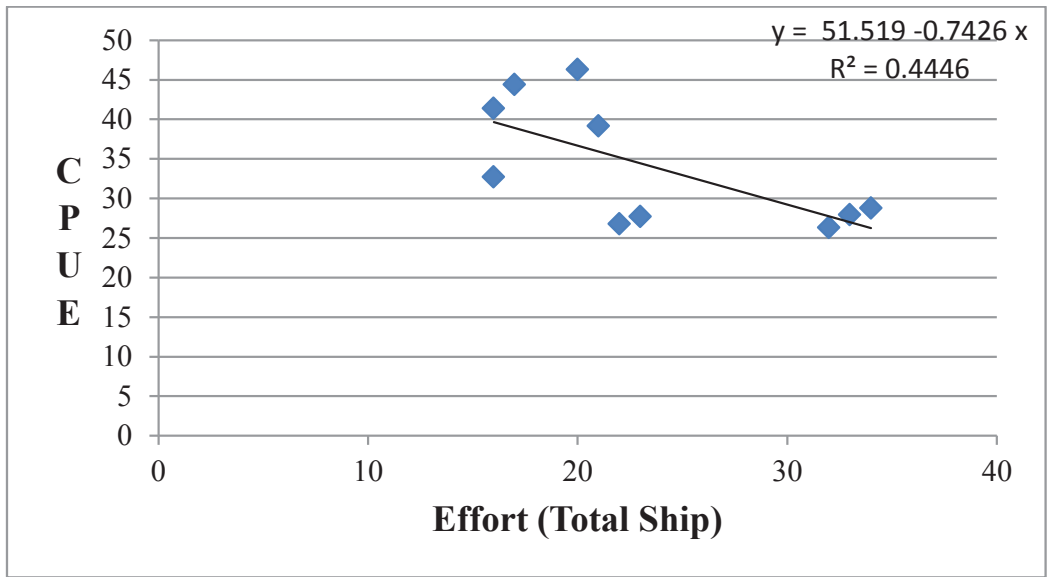

Fig. 2. Regression of Stingray Fish Catch Effort and CPUE 2006 - 2015

Regression graphic (figure 2) between catch effort and CPUE of Stingray fish showed negative relation, higher the effort value then the value of CPUE decreased. Regression analysis resulted in equation value of relation between catch effort and production $\mathrm{Y}=51.519-0.7426 \mathrm{X}$ with $\mathrm{R}^{2}=0.4446$.

The result showed that the value of one ship in catching stingray in Kejawan Nusantara Fisheries Port was 51.519. Slope (b) value was -0.7426 , negative in value can be interpreted as every increase in catch effort will decrease CPUE value by 0.7426 . Increase in catch effort will decrease CPUE value [8]. R value was 0.4446 or $44 \%$ interpreted as effort had high influence over CPUE, other 56\% were seasons, machine, and fishing ground. Factors that affect CPUE was far fishing ground and change of nature [9].

\subsection{Maximum Sustainable Yield (MSY) Analysis}

Regression was used to calculate optimum catch result (MSY) and optimum catch effort (fMSY). Schaefer model was used :

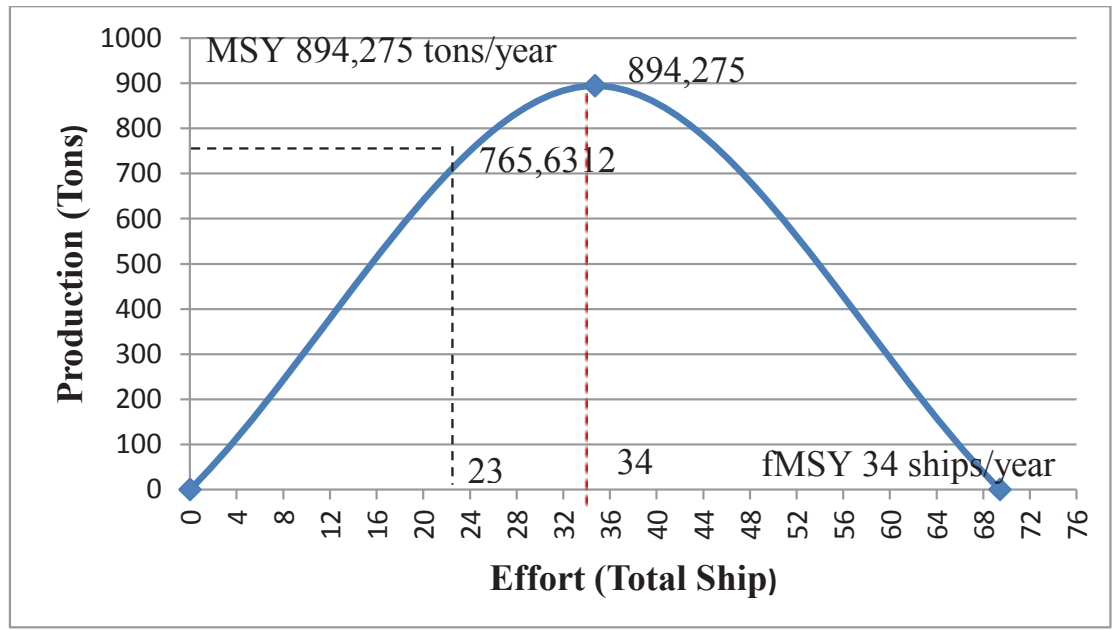

Fig. 3. Maximum Sustainable Yield (MSY) curve of stingray fish 2006- 2015 (Source : Annual Statistic Report of Kejawanan Nusantara Fisheries Port 2015)

Based on curve (figure 3) Schaefer model, stingray fMSY value was 34 ships/ year and MSY value was 894.275 tons/year. Statistical report recording 23 ships was used. The effort of catch in $2006-2015$ did not exceed optimum value.

Stingray fish potential of sustainable (MSY) calculated using Schaefer model was 894.275 tons/year. Based on production data and statistical report of stingray fish production value was 765.6312 tons/year. The result showed stingray fish catch was still under fishing and sustainable. Resource utilization value was $80 \%$ from MSY, if the value is lower than $80 \%$ it is called underfishing and can be further improved but not exceeding the MSY value [10]. 


\subsection{Stingray Species}

Stingray fish species catched and recorded during the research:

Table 1. Stingray species catched and recorded during research

\begin{tabular}{|c|c|c|c|}
\hline No & Species & Local Name & Total \\
\hline 1. & Dasyatis zugei & Sharp nosed ray & 163 \\
\hline 2. & Dasyatis kuhlii & Oil ray & 113 \\
\hline
\end{tabular}

\subsection{Stingray fish sex ratio}

3.5.1. Sharp nosed ray (Dasyatis zugei) sex ratio

Recorded 77 male fish and 86 female fish catched during the research, the sex ratio of sharp nosed ray fish was 1.00 : 1.10. The result showed sharp nosed ray sex ratio was still balanced.

\subsubsection{Oil ray (Dasyatis kuhlii) sex ratio}

Recorded 48 male fish and 65 female fish catched during the research, the sex ratio of oil ray fish was $1.00: 1.35$. The result showed oil ray sex ratio was still balanced .

\subsection{Length frequency distribution}

\subsubsection{Sharp nosed ray leght distribution}

The length distribution of sharp nosed ray can be seen on figure 4 .

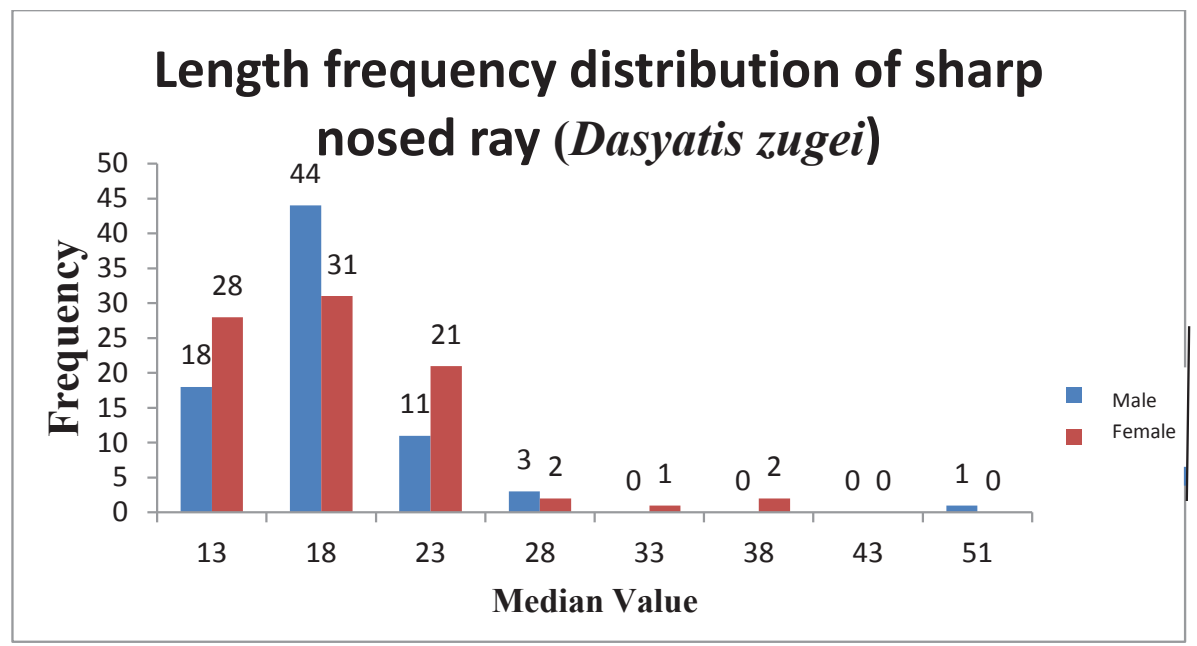

Fig.4. Graphic of legth distribution of male and female sharp nosed ray (Dasyatis zugei)

High distribution of sharp nosed ray length is $16-20 \mathrm{~cm}$ with the composition of 44 male and 31 female. The highest length of sharp nosed ray was $16-20 \mathrm{~cm}$. Young (immature gonad) sharp nosed ray (Dasyatis zugii) length between $10 \mathrm{~cm}-17 \mathrm{~cm}$. Length of sharp nosed ray with riped gonad are $19.1 \mathrm{~cm}$ female and $17.8 \mathrm{~cm}$. It can be concluded $16 \mathrm{~cm}-20 \mathrm{~cm}$ length sharp nosed ray is fish that with immature and first riped gonad. 


\subsubsection{Oil Ray length distribution}

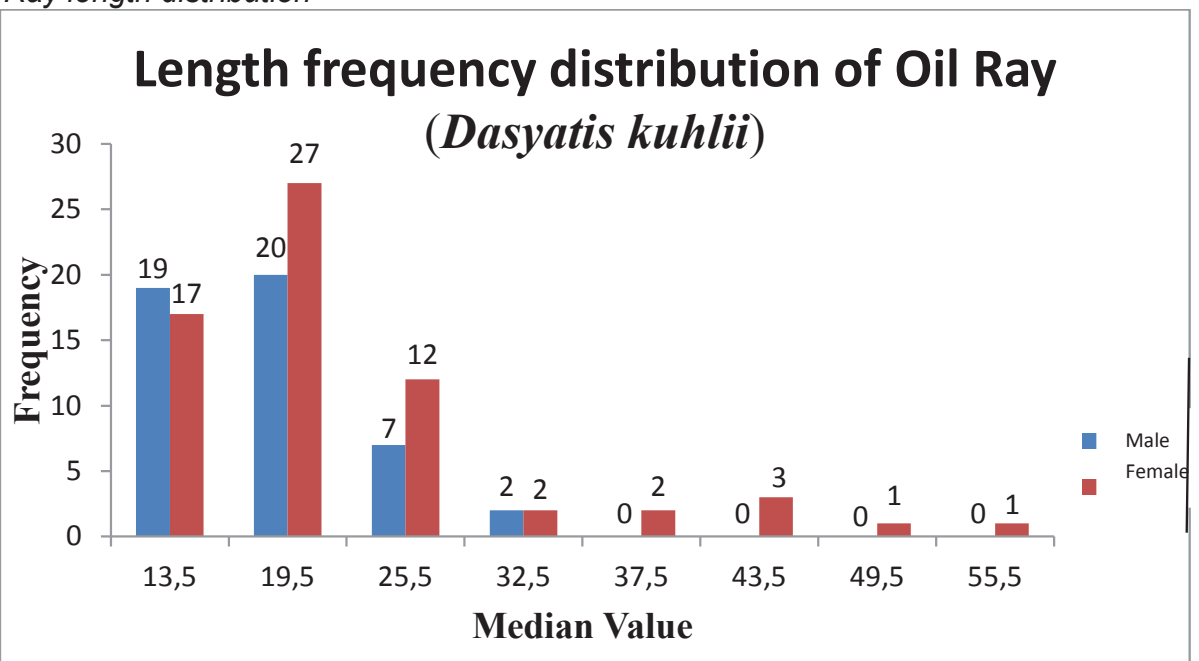

Figure 5. Graphic of legth distribution of male and female oil ray (Dasyatis kuhlii)

Oil ray highest leght distribution for male was $19.5 \mathrm{~cm}$ and for female was $17 \mathrm{~cm}-22 \mathrm{~cm}$, with 20 male and 27 female fish. Oil ray population was dominated by immature gonad fish with $17 \mathrm{~cm}-22 \mathrm{~cm}$ in leght. Immature gonad Oil ray fish (Dasyatis kuhlii) have length between $12 \mathrm{~cm}-26 \mathrm{~cm}$. The sample caught during the research dominantly oil ray fish that did not ripe.

The high number of immature gonad fish caught in the fishing activity can fisheries resources, the damage will increase if the fishes caught have low respawn rate. Catch fisheries activity that catch immature fish will damage the fish life cycle and endangering it is population.

\section{Conclusion}

The conclusion of this research is, from the MSY result it can be interpreted that Stingray fishing in Java Sea is still underfishing. There is two type of stingray caught during the research namely sharp nosed ray Dasyatis zugei and oil ray Dasyatis kuhlii with balanced sex ratio. The fish caught is still young (immature gonad) observed from caught fish lenght ratio. Further research and technology are needed to do fisheries activity to sustain the fish resources.

\section{Refferences}

1. Susanto, E. dan A.S Fahmi. Senyawa Fungsional dari Ikan : Aplikasinya dalam Pangan. Jurnal Aplikasi Teknologi Pangan. 1 (4) : 95 - 102. (2012)

2. Budiharsono, S. Teknik Analisis Pembangunan Wilayah Pesisir dan Lautan. Jakarta: Pradnya Paramita. (2001)

3. Nelson JS. 1994. Fishes of The World Third Edition. New York: John Wiley \& Sons, Inc.

4. Dinas Perikanan Propinsi Jawa Barat. Buku Tahunan Statistik Perikanan Tangkap Jawa Barat 2006. Pemprov Jawa Barat, Dinas Perikanan. Bandung. (2006)

5. Widodo A.P.A. Pemanfaatan dan Pengelolaan Sumberdaya Ikan Pari di Laut Jawa. Tesis. Sekolah Pascasarjana Institut Pertanian Bogor. (2004)

6. Budiman. Analisis Sebaran Ikan Demersal sebagai Basis Pengelolaan Sumberdaya Pesisir di Kabupaten Kendal. Tesis. Sekolah Pascasarjana Universitas Diponegoro, Semarang.114 hal. (2006)

7. Purwanto. Makalah Pengelolaan Sumberdaya Ikan. Disajikan Pada Workshop Pengkajian Sumberdaya Ikan. (2003)

8. Cahyani, R.T., Sutrisno A., dan Bambang Y. Potensi Lestari Sumberdaya Ikan Demersal (Analisis Hasil Tangkapan Cantrang yang didaratkan di TPI Wedung Demak). Prosding Seminar Nasional Pengelolaan Sumberdaya Alam dan Lingkungan. 378-383 hal. (2013)

9. Prihartini, A. Analisis Tampilan Biologis Ikan Layang (Decapterus sp) Hasil Tangkapan Purse Seine yang didaratkan di PPN Pekalongan. Tesis. Universitas Diponegoro. Semarang. 25 hal. (2006)

10. Anugrahini, D. R. Analisis Pengaruh Penurunan Stok Ikan Terhadap Pendapatan Nelayan Kecamatan Muncar, Banyuwangi, Jawa Timur. Tesis. Universitas Diponegoro. Semarang. (2011) 